\title{
Design and validation of educational material aimed at adults with Heart Failure
}

\author{
Diseño y validación de material educativo dirigido a adultos con Falla Cardíaca \\ Desenho e validação do material educativo dirigido a adultos com insuficiência cardíaca
}

\author{
Eugenia del Pilar Herrera-Guerra* \\ Viviana Marycel Céspedes-Cuevas**
}

\begin{abstract}
Objective: Design and validate educational material aimed at adults with heart failure as an intervention of the disease centered on the decision making for the management of the symptoms. Materials and methods: Methodological study made following the Guide for the design, use and evaluation of educational material about health and the instrument of Specific Guidelines for the Evaluation of printed education materials developed by the Pan American Health Organization. For the design a group of 2 adults with heart failure, 2 caregivers, 2 nurses and 1 cardiologist participated. The educational material in its preliminary design was subject of evaluation by experts $(n=7=$ and by adults with heart failure $(\mathrm{n}=10)$. Results: The design of educational material (pamphlet) is supported by the Situation-specific Theory of heart failure self-care and its empirical indicator is the scale of Self-care of Heart Failure Index. The experts and adults with heart failure who participated on this study agreed that the pamphlet meets the criteria of potential effectiveness on all the educational material. The scores obtained in the specific guidelines indicated that it should be used as designed and some evaluators indicated that the design should have some changes from the preliminary version. The production of the final version was made considering the observations of the evaluators. Conclusions: The steps for the design and validation of educational material are explained in detail and supported by the nursing theory and is made available to be used in the practice and research.
\end{abstract}

Keywords: Health education, selfcare, self-management, cardiovascular diseases.

\section{Resumen}

Objetivo: Diseñar y validar material educativo dirigido a adultos con Falla Cardíaca para una intervención de enfermería centrada en la toma de decisiones para el manejo de los síntomas. Materiales y métodos: Estudio metodológico realizado siguiendo la Guía para el diseño, utilización y evaluación de material educativo en Salud y el instrumento de Pautas Específicas para Evaluación de material educativo impreso, desarrollados por la Organización Panamericana para la Salud. En el diseño participó un grupo conformado por 2 adultos con Falla Cardíaca, 2 cuidadores, 2 enfermeras y

\section{Autor de correspondencia}

* $\triangle \mathrm{PhD}$ in Nursery. Full Professor. Universidad de Córdoba. Facultad de Enfermería. E-mail: edherrera@correo.unicordoba.edu. co ORCID: 0000-0001-8413-4935, Córdoba, Colombia.

** $\mathrm{PhD}$ in Nursery. Posdoctorate in Narrative and Science. Associate Professor, Universidad Nacional de Colombia - Bogotá-Facultad de Enfermería. E-mail: vmcespedesc@unal. edu.co . ORCID: 0000-0001-9728-0704, Bogotá, Colombia. 
ISSN-PRINT

1794-9831

E-ISSN 2322-7028

Vol. 17 No. 1

Ene - Abr 2020

Cúcuta, Colombia

un 1 cardiólogo. El material educativo en su diseño preliminar fue sometido a prueba por expertos $(\mathrm{n}=7)$ y por adultos con Falla Cardíaca $(\mathrm{n}=10)$. Resultados: El diseño del material educativo tipo folleto está sustentado en la Teoría de Situación Especifica Autocuidado en Falla Cardíaca y su indicador empírico es la escala Self-care Heart Failure Índex. Los expertos y los adultos con Falla Cardíaca que participaron en el estudio convinieron en que el folleto cumple con los criterios de efectividad potencial de todo material educativo. Los puntajes obtenidos en las pautas específicas indicaron que se debe usar como está diseñado y algunos evaluadores indicaron algunas reformas a la versión preliminar. La producción de la versión definitiva se realizó atendiendo las observaciones de los evaluadores. Conclusiones: Se detallan los pasos para el diseño y validación de un material educativo sustentado en una teoría de enfermería y se pone a disposición para ser utilizado en la práctica y la investigación.

Palabras clave: Educación en salud, autocuidado, automanejo, enfermedades cardiovasculares.

\section{Resumo}

Objetivo: Desenhar e validar material educativo dirigido a adultos com insuficiência cardíaca para uma intervenção de enfermagem centrada na toma de decisões para o manejo dos sintomas. Materiais e métodos: Estudo metodológico realizado seguindo a Guia para o Desenho, Utilização e avaliação de Material Educativo em Saúde e o instrumento Pautas Específicas para a Avaliação de Material Educativo Impresso, ambos desenvolvidos pela Organização Pan-Americana da Saúde. No desenho participaram um grupo que contava com 2 adultos com insuficiência cardíaca, 2 cuidadores, 2 enfermeiras e 1 cardiologista. O material educativo prelimitar submeteu-se a provas por expertos $(n=7)$ e por adultos com insuficiência cardíaca $(n=10)$. Resultados: O material desenhado fundamentou-se na teoria de situação específica "Autocuidado em Insuficiência Cardíaca" e o seu indicador empírico foi a escala Self-care Heart Failure Index. Os expertos e os adultos com insuficiência cardíaca que participaram no estudo concordaram na determinação que o material educativo cumpre com critérios de efetividade potencial de todo material educativo. As pontuações obtidas nas pautas específicas indicaram que deve empregar-se como foi desenhado e alguns dos avaliadores sugeriram algumas modificações na versão preliminar. A produção da versão definitiva realizou-se atendendo as recomendações dos avaliadores. Conclusão: Foram descritos em detalhe as etapas para o desenho e validação do material educativo sustentado na teoria de enfermagem e se põe a disposição para ser utilizado na prática e em pesquisa.

Palavras-chave: Educação em saúde, autocuidado, doenças cardiovasculares, insuficiência cardíaca

\section{Introduction}

Heart failure (HF) is a health problem that affects millions of people globally in terms of morbidity, mortality and costs of constant hospitalizations (1-3). According to Will et al. (4), the main cause of hospitalizations is due to the lack of control of the symptoms of HF. Boyde et al. (5) demonstrated in a study that a solution to reduce the risk of hospitalization due to $\mathrm{HF}$, the maximization of pharmacotherapy and self-care is required.

The literature review about interventions to improve the health results of adults with HF $(1,6-8)$ reports that multidisciplinary intervention with follow up and education, are the most frequent the strategies in the clinical essays made in the last years. Various authors agree in stating that innovative educational strategies are necessary to help patients with HF adapt to their chronic condition and assume the responsibility of self-care (1, 8-11).
Its undeniable that experimental studies made on patients with HF have produced a variety of educational materials; however, it is important to consider that not all of the material has the expected impact of an intervention that proposes to improve self-care for $\mathrm{HF}$, which frequently causes on the researcher to design educational material according to the objectives that have been traced in the intervention protocol.

Although there exists a high number of publications of clinical essays made on patients with HF which have been analyzed in systematic and meta-analysis reviews, $(1,6-8)$, the evidence of the design and validation process of the educational material used is low. Therefore, it is necessary to publish the criteria that has been considered for the design and evaluation of the educational material used in the interventions which have been proved, in experimental studies, as efficient, for the improvement of self-care in adults with HF. 
The present study emerges from the need of designing and validating educational material that responds to the learning objectives, previously formulated in the intervention protocol of an aleatory clinical essay made to determine the efficiency of a nursing intervention, centered on the decision making for the management of symptoms on an adult with HF, theoretically supported in the Situation-specific Theory of heart failure self-care (12-13).

The Situation-specific Theory of heart failure self-care was selected because of its novelty, thoroughness, recency, range, depth and extent with which is described; as well as the way it explains and predicts the phenomena of self-care in adults with HF and is also adapted to the objective and the necessities of the population of the study.

It is important to mention that the intervention strategies that make up the active ingredients responsible for inducing the desired changes through intervention, were identified through theoretical analysis of The Situationspecific Theory of heart failure self-care, which allows to explicitly identify the strategies that should be implemented to achieve changes in the processes of self-care (maintenance, perception of symptoms and process), based on the theoretical proposition that affirms, that selfcare is influenced by knowledge, experience, skills and compatibility with values (13).

Once the active ingredients of the intervention protocol were defined, the need for designing and validating educational material that allows to help adults with HF emerged, to facilitate decision making to manage the symptoms, and consider the processes of self-care. Also, it would be of complement to acquire knowledge about the situation, develop skills and experience for taking decisions and doing actions, with the purpose of having control of the symptoms of HF.

Starting from the premise on which it is considered that intervention is centered on decision making for self-care in HF, its important to make clear that the intervention strategies (active ingredients) transcend the education component (knowledge), supporting the action (skills and experiences in decision making) and the compatibility with personal values defined in the Riegel's theory (12-13).

From this perspective, the theoretical framework of the educational material designed is based on The Situationspecific Theory of heart failure self-care (12-13) and its empirical indicator is the scale Self-care of Heart Failure
Index version 6.2 (SCHFI V6.2) developed by Riegel et al. (14), which is based on an intervention protocol, that allows the application of the disciplinary knowledge of nursing in research and practice.

Therefore, the importance of this study is mainly in making available an educational material that can be used by people interested in replicating the intervention, based on the need of having empirical indicators that facilitate the application of nursing theories in the practice.

\section{Objective}

\section{General Objective}

Design and validate educational material aimed at adults with HF for a nursing intervention, centered on the decision making for the management of symptoms.

\section{Specific objectives}

- Design educational material according to the learning objectives formulated on the nursing intervention, centered on the decision making for the management of HF symptoms.

- Validate the educational material through the evaluation of specific criteria established for printed material.

\section{Materials and methods}

The study corresponds to a methodological research, consisting of four phases: design, usage, evaluation and production of the definite version of educational material for health, following the guide developed by the Pan American Health Organization (PAHO) (15).

1 Design. The stages developed on this phase were: organization of content, selection of messages and illustrations, elaboration of the first version of the material. In the design phase participated a group made by $3 \mathrm{HF}$ experts ( 2 nurses and 1 cardiologist), 2 adults with $\mathrm{HF}$ and 2 caregivers of adults with HF.

2. Usage. In this phase the instructions for the educational material were made. Also, a brief and precise written explanation was added about when, how and who to use this material with.

3. The educational material design was subject on evaluation before its final version and diffusion, to establish 
ISSN-PRINT

1794-9831

E-ISSN 2322-7028

Vol. 17 No. 1

Ene - Abr 2020

Cúcuta, Colombia its potential effectiveness, considering five aspects: attraction (awakens and maintains the attention of the individual), comprehension (a message that is easy to understand), acceptance (a message that is coherent with the cultural norms of the locality), identification (the message is relevant for the targeted individuals, interprets the images and language) and persuasion (the message is convincing enough to achieve changes in the desired attitude and behavior).

It should be clarified that these aspects were evaluated on a scale from 1 to 5 , according to the amount of compliance, where 5 corresponds to total compliance and 1 indicates no compliance.

To validate the educational material, the specific criteria established in the instrument for specific guidelines were considered for the evaluation of printed material of the PAHO (15), which was validated in Colombia by Barrera et al. (16), reporting an alpha Cronbach of 0,83 ; the extraction of the main components produced only one factor that explains $45.1 \%$ of the total variance.

For its part, the instrument of specific guidelines for evaluation of the printed material consists of 9 items that are classified in a scale from 1 to 5 according to the amount of compliance, where 5 corresponds to total compliance and 1 indicates no compliance (minimum score of 9 and maximum score of 45). The decision of accepting, changing or declining the instrument is based on the total score according to the following ranges: less than 20 decline, 20-39 change and 40-45 accept.

Similarly, the preliminary design of the pamphlet was subject of evaluation by nursing professionals, experts in the area of HF $(n=7)$, selected for their knowledge and practical and/or research experience in education for self-care aimed at adults with HF, these professionals came from various parts of Colombia. In this phase also participated adults with a confirmed diagnosis of HF $(n=10)$ from different healthcare institutions, with recent experience of HF symptoms, who knew how to read and write, and without physical, cognitive and/or sensory detriments. In all the study phases the compliance of the ethical considerations for health research were met
(17-18). The approval from the Ethics Committee $\left(\left(\mathrm{N}^{\circ}\right.\right.$ 008-17), and the institutional approval and the informed consent of the participants were obtained.

\section{Results}

The design of the educational material started from the implementation of the Conceptual-Theoretical-Empirical System (CTE) described by Fawcett and Garity (19), represented in graphic 1. Starting with the concept of self-care, defined by the Situation-specific Theory of heart failure self-care (13), as a natural process of decision making that influences the actions to maintain physiological stability, facilitate the perception of symptoms and control the management of symptoms.

Secondly, the theoretical propositions that delimit the three processes that self-care implies for HF were reviewed. According to Riegel, et al. (13), the first process refers to the maintenance of self-care, perceiving the adherence to the treatment and healthy behaviors. The second process, related to the perception of symptoms, involves the detection of physical sensation and the interpretation of significance. The third process of self-care is the control or the response to the symptoms when these show up.

Lastly, the scale of Self-care Heart Failure Index version 6.2 SCHFI V6.2 (14), as the empirical index of the theory, was studied. Barbaranelli et al. (20) determined the validity of this construct of the scale through confirmatory factor analysis, using different scales (Cronbach, standardized, composed reliability, maximum reliability, determination of score of the factors); similarly, multidimensionality presented by the scales of maintenance (4 factors), control (2 factors) and confidence ( 1 factor) were considered. These components determined that the internal consistency varied positively in the 3 scales: maintenance $(0,75$ to 0,83$)$, control $(0,66$ up to 0,77$)$ and confidence $(0,84$ to 0,90$)$; demonstrating that it is a valid, reliable and useful measure for the researchers, to test the efficiency of the interventions under the theoretical hypotheses of the Situation-specific Theory of heart failure self-care 


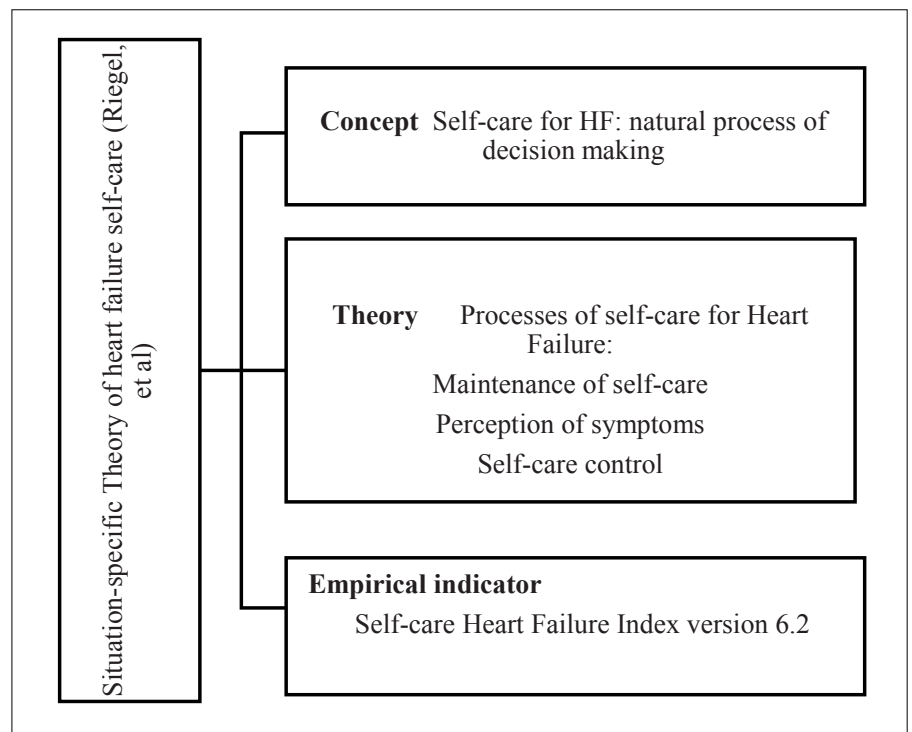

E-ISSN 2322-7028

Vol. 17 No. 1

Ene - Abr 2020

Cúcuta, Colombia

Graphic 1. Theoretical framework supported by the Situationspecific Theory of heart failure self-care. Implementation of the CTE system.

Authors: Herrera y Cespedes.

\section{Design of the educational material}

Considering the personal factors that may influence the natural decision making, such as culture, education and socioeconomic environment, the design of a pamphlet was chosen for being a printed educational material that can be easily transported, be used in different contexts and at different moments; also, there is no need for additional equipment for its use, which can facilitate the quick access to information. Also, it should be clarified that adults with HF usually do not have the resources and skills for the use of technologies.

The organization of the content of the preliminary version was made through a planning matrix, making emphasis in the actions to maintain self-care, the perception of symptoms and control of the symptoms which are contemplated in the scale SCHFI V6.2 in its Spanish version which was culturally adapted and validated for Colombia (Chart 1).

After defining the content, the preliminary version of the pamphlet was designed with the participation of the HF experts $(n=3)$, patients with HF $(n=2)$ and caregivers of patients with $\mathrm{HF}(\mathrm{n}=2)$. It was planned in written form and there were drawings designed expressing the main ideas. With the purpose of presenting a central narrative thread, a character named Tomas was created, showing images with daily situations to strengthen the written messages. The main ideas were highlighted by size, position and color to facilitate preciseness and comprehension of the message, using easy words, short phrases, drawing designs that illustrate what's written, and allowing to apply what was learned.

The name of the character was made by uniting the first letters of the keywords from the title of the pamphlet Decision making for HF symptoms (using the Spanish acronym). This way, the letters contributed on the construction of written and visual messages that strengthen the necessary instructions to make self-care actions, organizing them by following the mnemonic technique of the word TOMAS (Chart 2). Subsequently, another character called TOMASA was created to represent women, which was useful to recognize the importance of gender identity, allowing to define the subtitle of the pamphlet: reminder for TOMAS and reminder for TOMASA. 
ISSN-PRINT

1794-9831

E-ISSN 2322-7028

Vol. 17 No. 1

Ene - Abr 2020

Cúcuta, Colombia

Chart 1. Planning matrix for the design of the preliminary version of the pamphlet. Decision making for the management of HF symptoms: first process, maintenance of self-care

\begin{tabular}{|c|c|}
\hline $\begin{array}{l}\text { Ítems de la escala Self-care Heart Failure Index } \\
\text { V6.2 Español, Colombia. Sección A: Adheren- } \\
\text { cia al tratamiento y comportamientos saludables }\end{array}$ & $\begin{array}{l}\text { Decision making to manage HF symptoms. Section A: I } \\
\text { take care of myself }\end{array}$ \\
\hline $\begin{array}{l}\text { - \#8. Do you forget to take some of your } \\
\text { medicine? } \\
\text { - \#10. Do you use a system (pill cases, } \\
\text { reminders) to help you remember to take your } \\
\text { medicine? } \\
\text { - \#3. Do you try to avoid getting sick? (eg., } \\
\text { getting the flu shot or avoiding sick people) } \\
\text { - \#4. Do you do physical activity? (eg., clean } \\
\text { the dust, walk, gardening, domestic chores) } \\
\text { - \#7. Do you do physical excersise? } \\
\text { - \#5. Do you attend to medical and nursing } \\
\text { appointments? } \\
\text { - \#6. Do you have a food diet low in salt? } \\
\text { you go you order food that has low salt when } \\
\text { youtside or with other people? }\end{array}$ & $\begin{array}{l}\text { - T - TAKE ALL MY MEDICINE. I never forget to take my } \\
\text { medicine. I use a system daily (pill case, reminder, alarm) to } \\
\text { help me remember to take my medicine. } \\
\text { - O - MAIN OBJECTIVE. My main objective is to take care } \\
\text { of myself. I avoid getting sick. I am vaccined against the flu. } \\
\text { - M - MAINTAIN A DAILY EXCERSISE ROUTINE. I } \\
\text { always do physical activity (gardening, domestic chores, } \\
\text { walk). I do } 30 \text { minutes of physical excersise daily. } \\
\text { - A - ALWAYS ATTEND TO MEDICAL AND NURSING } \\
\text { APPOINTMENTS. I use an appointment calendar to } \\
\text { remember the date and time of medical and nursing } \\
\text { appointments. } \\
\text { - S - I ALWAYS EAT FOODS LOW IN SALT. At home I eat } \\
\text { foods low in salt. When I eat outside I order food low in salt. } \\
\text { - I support cooking foods low in salt. }\end{array}$ \\
\hline
\end{tabular}

Authors: Herrera y Cespedes

Chart 2. Planning matrix for the design of the preliminary version of the pamphlet. Decision making to manage the HF symptoms: second process, control of self-care.

Items of the scale Self-care Heart Failure Index V6.2

Spanish, Colombia. Section A: control of the symptoms of HF. Section B: self-care management

-\#1. Do you weight yourself?

- \#2. Do you check if your ankles are swollen?

- If you have had respiratory problems or swollen ankles during the past month.

- \#11. How fast did you recognize a simptom of Heart Failure?

- If you have any respiratory problems or swollen ankles, what is the probability of you trying one of these measures?

-\#12. Lower the salt on your diet

- \#13. Lower liquid intake

- \#14. Take an extra diuretic pill

- \#15. Call your doctor or nurse for help
Pamphlet: Decision making for managing the symptoms

of HF. Section B: I can recognize, evaluate and respond to the HF symptoms

- I weight myself daily

- I check if my ankles are swollen daily

- I keep record of symptoms and events

- Remember: retention of liquids in the body can cause swollen ankles and legs, gain weight, heavy breathing and fatigue or tiredness

- T- I MAKE DECISIONS to respond to the symptoms when these show up

- O - OBSERVE AND LISTEN TO MY BODY. I can easily recognize the Heart Failure symptoms

- M - MANAGE THE SYMPTOMS. I lower the salt and liquids on my diet, I take a diuretic pill.

- A - ALERT. I alert my family and/or caregiver

- S - ASK FOR HELP. I evaluate if the treatment improves the symptoms. I inform my doctor and/or nurse

- Self-care: I make decisions for the management of HF symptoms.

Authors: Herrera y Cespedes.

The pamphlet in its preliminary version was elaborated by a graphic designer, following the indications defined by the participating group of the design, working together in the creation of a character, images, and the achievement of the objectives of the principles of economics about space (image location) and language (speech that accompanies the image), always preserving the content.

\section{Instructions for the use of the educational material}

The pamphlet comes along with instructions for its use, explaining precisely who it is aimed for, and when, how and where to use it, as detailed next. Suggestions for the educational agent. This pamphlet has been created for adults with $\mathrm{FH}$, it can be used in different contexts (hospital, ambulatory, domiciliary), at different moments 
(doctor's or nursing appointments, individual and group interventions) and by different users (people with HF, healthcare personnel and caregivers).

The content of the pamphlet must be supported by standard or regular education, recommended by the national and international guides for attention with the purpose having respect for the freedom of decision, instead of manipulating the audience. It can be considered as an additional reminder supported by the Intervention Protocol for Decision Making for HF Symptoms.

It can also be used to strengthen decision making knowledge, experience and skills to manage HF symptoms, considering the personal values and the context. For this, some questions are asked; first a description of what is seen, then about what feelings and emotions produce the images, and finally learning is explored. It is recommended to ask the following questions:

1. What images do you see? Guide the person to describe what they observe.

2. Does it cause interest you? or what emotions do the images cause on you? support the person to express their thoughts, feelings and desires considering what they observe in the pamphlet.

3. What do you think about the recommendations and actions the characters (Tomas-Tomasa) from the pamphlets have to do to maintain good health? Mo- tivate the person to express their values (what they think is good or bad for their health).

What experiences do you have? What have you seen or heard about managing HF symptoms? Orientate the person to share their experiences, knowledge and skills about recommendations of management of self-care and decision making for self-care control.

Do you think you can do what the character from the pamphlet does? The approach to values must be simple and easily understood. Strengthen the positive values and explain the harm or consequences of negative values.

What did you learn about the messages given by Tomas? At the end of the session, evaluate if the person wants to strengthen or go more in depth on the subject.

The achieved objectives can be evaluated using the scale of Self-care of Heart Failure Index, the empirical indicator of the Situation-specific Theory of heart failure self-care.

\section{Evaluation of the preliminary version}

The preliminary version of the pamphlet was subject to evaluation by HF experts $(\mathrm{n}=7)$ and adults with $\mathrm{HF}$ $(n=10)$ to establish the potential effectiveness and the compliance of the specific guidelines following the PAHO guides (16). Most participants rated the aspects that evaluate the potential effectiveness between 4 and 5 points (Table 1) indicating that the criteria of attraction, comprehension, acceptance, identification and persuasion were met.

Table 1. Potential effectiveness of the pamphlet Decision making to manage HF symptoms. Reminder for Tomas - Reminder for Tomasa. Colombia, 2017.

\begin{tabular}{|c|c|c|c|c|c|c|c|c|c|c|}
\hline \multirow{2}{*}{ Criteria } & \multicolumn{5}{|c|}{ HF experts $(n=7)$} & \multicolumn{5}{|c|}{ Adults with HF $(n=10)$} \\
\hline & 1 & 2 & 3 & 4 & 5 & 1 & 2 & 3 & 4 & 5 \\
\hline Attraction & & & & $33 \%$ & $67 \%$ & & & & $40 \%$ & $60 \%$ \\
\hline Comprehension & & & & $67 \%$ & $33 \%$ & & & & $60 \%$ & $40 \%$ \\
\hline Acceptance & & & $33 \%$ & & $67 \%$ & & & $20 \%$ & $20 \%$ & $60 \%$ \\
\hline Identification & & & & $33 \%$ & $67 \%$ & & & & $20 \%$ & $80 \%$ \\
\hline Persuasion & & & $17 \%$ & $50 \%$ & $33 \%$ & & & $20 \%$ & $60 \%$ & $40 \%$ \\
\hline
\end{tabular}

Source: data base of the study. Authors: Herrera y Cespedes.

The nine criteria that evaluate the specific guidelines of the printed material (pamphlet) were rated by the group of experts and by the group of adults with HF with a minimum score of 37 and a maximum score of 45 ; the scores obtained were mainly in the range of use as it is (Table 2). 
Table 2. Evaluation of the specific guidelines of the pamphlet Decision making for managing the symptoms of HF. Reminder for Tomas - Reminder for Tomasa. Colombia, 2017.

\begin{tabular}{lll}
\hline Score & HF experts $(\mathrm{n}=7)$ & Adults with $\mathrm{HF}(\mathrm{n}=10)$ \\
\hline Use as it is (40 a 45) & $71,5 \%$ & $60 \%$ \\
Needs adjustments (21 a 39) & $28,5 \%$ & $40 \%$ \\
Declined (<20) & 0 & 0 \\
\hline
\end{tabular}

Source: data base of the study. Authors: Herrera y Cespedes.

The observations given by the experts were satisfactory and expressed the following appreciations: "I think it is good education material to implement in HF clinics", "it is a useful tool for the nursing practice and for the care of patients with HF", "I would love to have permission to use it", "it is excellent educational material for its precise content aimed at a specific group of patients".

Similarly, the scores obtained for the filled forms from the adults with HF who participated on the study, allowed to determine through the items of the instrument, that the content from the pamphlet is easy to understand (item \#2) and that it uses a language that the community is able to understand (item \#9). The participants felt identified with the characters TOMAS and TOMASA.

\section{Production of the final version}

The final version of the pamphlet was made considering the observations made by the experts who considered that the content written in the preliminary version of the pamphlet needed some changes $(28,5 \%)$, as presented below.

1. I TAKE CARE OF MYSELF. Recommendation: make the target visible: I care for my welfare or something similar. Final version: I care for my health and welfare.

2. REMEMBER: retention of liquids can cause swollen ankles and legs, gain weight, heavy breathing and fatigue or tiredness. Recommendation: maintain the semantic of the first person. I remember that or I have present that. Final version: I have present that: the retention of liquids can cause swollen ankles and legs, gain weight, heavy breathing and fatigue or tiredness.

3. A - I WARN my family and/or caregiver. Observation: the idea is not complete. Add in case the symptoms don't get better. Final Version: I warn my family and/or caregiver in case my symptoms don't improve.
For their part, caregivers and patients (40\%) recommended to increase the size of the font and images. The suggested adjustments were made, making emphasis on the main messages.

It is important to make clear that this pamphlet does not try to aboard all the necessities and interests of learning that adults with HF may have, its function is to strengthen or broaden the education given in the sessions of the Intervention Protocol for Decision Making for HF Symptoms, therefore, it responds to the design of educational materials for the learning of a specific subject. It is a support to achieve the objectives, making emphasis on the contest of educational interest that seek to achieve an integration of all the elements for self-care, defined as a process of decision making supported by the situationspecific theory of heart failure self-care.

\section{Discussion}

With these findings, the study highlights the importance of the participation of the population to whom the educational material is aimed at, both in the design phases as well as in the validation phase, to be able to respond to the objectives that an educational program wants to reach; also, it must maintain its preciseness, evaluations and guarantee its effectiveness (15).

According to the results of the evaluation, the experts' perspective considered as valid the evaluated items of the specific criteria with the highest score (use as it is); in contrast with the responses of the adults with HF that participated. On the other hand, the criterions of attraction, acceptance and identification presented the best evaluation results, demonstrating the potential effectiveness of the educational material.

These findings are important, considering the findings of similar studies, such as the study of Correa (21) who designed a pamphlet for a nursing intervention, based on the educational recommendations for patients with a coronary stent placement. From this, through the process of 
validation, the study was able to determine the potential effectiveness of the evaluated educational material.

Martinez and Cano (22) made the content validation of an educational tool, where all the specific criteria were in the range between 21 to 39, which corresponds to a decision that needs adjustments according to the PAHO guide (15). The authors made the correspondent changes and recommend doing the validation on a third phase, with the participation of the patients and their family members.

On the other hand, Fernandez (23) validated the educational material used (videos and pamphlets) in his study, it was applied to a nursing educational intervention in the agency of self-care for elder adults with hypertension. According to the results of the study, these indicate that the material can be a reliable didactic, which can be used by nursing in educational interventions, to strengthen the agency of self-care in elder adults with hypertension.

Considering the results compared to the objectives of the research, its necessary to discuss other aspects about the requirements of disciplinary knowledge and nursing practice, related to the role of education, which are fundamental parts of the care for adults with HF.

According to Paradis et al. (24) and Hernandez (25), the attention for the patient with HF requires multidisciplinary management, where the nursing personnel plays an important role to encourage education through structures interventions that guarantee not only knowledge, but the compliance of the recommendations given by the healthcare personnel.

For their part, Otsu and Moriyama (26) consider that for nursing, achieving the education objectives for the patients and their family is a challenge and therefore its necessary to properly plan the interventions. The planning of educational interventions includes the process of design and validation of the educational materials.

Valverde (27) supported by what Bartolome (28) affirms, recognizes that designing educational materials means initiating a series of complex actions, which are orientated to improve the communication processes made in education interactions and therefore, implies the planning and developing of proposals to produce materials that can be used and implemented.

Ziemendorff and Krause (29), define the validation of educational materials, as research made with the purpose of specific material aimed at a group of people or that intervene in its replication, to have an opinion on the materials that have been elaborated before these reach their final version, it seeks to comprehend the particularities of a specific group since these are the ones that point out their own characteristics. In virtue of the abovementioned, Lievano et al. (30) affirm that without validation, many of the interventions with educational material would complicate the determination of the achievement of the proposed objective.

It can be argued that there is no consensus about the quality of the educational materials that are designed for patients with HF, nor about the efficiency of the educational material used in the research and practice; however, there is a wide consensus that notes that the findings of the educational interventions are of great importance to improve the results in the health of patients with HF. There is, however, a debate about better evidence.

According to Fawcett and Garity (31) the final objective of nursing research is to achieve that the theories can be used in the practice activities. It is known, that the application of the theories in intervention protocols and new tools for practice is usually slow, because people needs time to think about change when exercising practice and then implementing that change.

On this subject, Meleis (32) estimates that the future for advancement in nursing knowledge, depends on the level of willingness to commit with the development of coherent frameworks, to promote future research programs and models for the practice. From this, the future of the nursing discipline abides in the use of specific theories for each situation, providing frameworks that are more accessible to the researchers and doctors.

It is convenient to note, that the advances of knowledge about self-care for HF, have achieved the development of conceptualizations that come closer to the clinic reality for the care of patients, giving origin to the Situationspecific Theory of heart failure self-care and its empirical indicator, the scale of Self-care of Heart Failure Index SCHFI V6.2. These are a reflection of the depth on the explanation of the self-care phenomenon for adults with $\mathrm{HF}$, which is of vital importance for translating the nursing research theory and practice.

This article published its design and validation of the educational material for the development of a nursing intervention, based on its own theory, as an example of how healthcare professionals can develop their own ideas about interventions that are based on theories. 
ISSN-PRINT

1794-9831

E-ISSN 2322-7028

Vol. 17 No. 1

Ene - Abr 2020

Cúcuta, Colombia
Although the coherence between these aspects can exist, there is few the evidence in the scientific literature. In this regard, Fawcett and Garity (31) consider that sometimes a proposal for a new intervention protocol or a new tool for practice, is based on a theory that is not related to a basic problem and to the interests for the population.

Under this premise, the research could be generating useful materials for science, but not practical due to its scarce connection between the educational material, the active component of the intervention and the theory that guides the intervention.

\section{Conclusions}

In this study the steps for making the educational material, based on an intervention protocol, allows to apply the nursing theories to the real world of research and practice. Therefore, it expands the use of theory in the practice, by making an educational pamphlet that connects the concepts explicitly in an educational material aimed at adults with HF; in this sense, the adequation and specification criteria, and the connections between the structural component of the empirical framework system were used.

The design and validation of a printed educational material (simple and practical pamphlet), focused on the patient, is built as a contribution for the expansion of the situation-specific theory of heart failure self-care and its use in the practice. It is recommended for future research, the use of evaluated and validated educational material and also to prove its efficiency in research and practice.

\section{Conflict of interests}

The authors declare not having any conflict of interests.

\section{Bibliographic references}

1. Jonkman NH, Westland H, Groenwold RH, Ågren S, Atienza F, Blue L, et al. Do self-management interventions work in patients with heart failure? An individual patient data meta-analysis. Circulation. 2016; 133(12):1189-98. DOI: http://doi.org/10.1161/CIRCULATIONAHA.115.018006

2. Ministerio de Salud y Protección Social. Departamento Administrativo de Ciencia, Tecnología e Innovación - Colciencias. Guía de práctica clínica para la prevención, diagnóstico, tratamiento y rehabilitación de la falla cardíaca en población mayor de 18 años clasificación B, C y D. Guía para profesionales de la salud 2016. Guía No. 53. 2016. 100 p. Disponible en: http://gpc.minsalud.gov. co/gpc sites/Repositorio/Conv 637/GPC falla cardiaca/GPC\%20Falla\%20Cardiaca\%20Profesionales $\% 20 \mathrm{No}_{0} 2053 . \mathrm{pdf}$

3. Grupo de Trabajo de la Sociedad Europea de Cardiología (ESC) de Diagnóstico y Tratamiento de la Insuficiencia Cardiaca Aguda y Crónica. Guía ESC 2016 sobre el diagnóstico y tratamiento de la insuficiencia cardiaca aguda y crónica. Rev Esp Cardiol. 2016; 69(12):1167.e1-e85. DOI: https://doi. org/10.1016/j.recesp.2016.10.014.

4. Will JC, Valderrama AL, Yoon PW. Preventable Hospitalizations for Congestive Heart Failure: establishing a baseline to monitor trends and disparities. Prev Chronic Dis. 2012; 9 (E85):110260. DOI: http://dx.doi.org/10.5888/pcd9.110260

5. Boyde M, Turner C, Thompson DR, Stewart S. Educational interventions for patients with heart failure: a systematic review of randomized controlled trials. J Cardiovasc Nurs. 2011; 26 (4):27-35. DOI: http://dx.doi.org/10.1097/JCN.0b013e3181ee5fb2

6. Oyangurena J, Latorre PM, Torcal J, Lekuona I, Rubio S, Maull S, et al. Efectividad y determinantes del éxito de los programas de atención a pacientes con insuficiencia cardiaca: revisión sistemática y metanálisis. Rev Esp Cardiol. 2016; 69(10):900-14. DOI: https://doi.org/10.1016/j.recesp.2016.05.008

7. Huntley AL, Johnson R, King A, Morris RW, Purdy S. Does case management for patients with heart failure based in the community reduce unplanned hospital admissions? A systematic review and metaanalysis. BMJ Open. 2016; 6(5):e010933. DOI: http://doi.org/10.1136/bmjopen-2015-010933 
8. Toukhsati SR, Jaarsma T, Badu AS, Driscoll A, Hare DL. Self-Care Interventions That Reduce Hospital Readmissions in Patients With Heart Failure; Towards the Identification of Change Agents. Clinical Medicine Insights: Cardiology. 2019;13:1-8. DOI: https://doi.org/10.1177/1179546819856855

9. Attaallah S, Klymko K, Pratt Hopp FP. Self-care among older adults with heart failure. Gerontol Geriatr Med. 2016; 2:1-10. DOI: https://doi.org/10.1177/2333721416684013

10. Riegel B, Masterson R, Hill J, Chittams J, Hoke L. Effectiveness of motivational interviewing in decreasing hospital readmission in adults with heart failure and multimorbidity. Clin Nurs Res. 2016; 25(4):362-77. DOI: https://doi.org/10.1177/1054773815623252

11. McGreal MH, Hogan M, Walsh Irwin C, Maggio N, Jurgens C. Heart failure self-care interventions to reduce clinical events and symptom burden. Res Rep Clin Cardiol. 2014; 5:243-57. DOI: https://doi. org/10.2147/RRCC.S48424

12. Riegel B, Dickson VV. A situation-specific theory of heart failure self-care. J Cardiovasc Nurs. 2008; 23(3):190-6. Disponible en: DOI: https://doi.org/10.1097/01.JCN.0000305091.35259.85

13. Riegel B, Dickson VV, Faulkner KM. The Situation-specific Theory of Heart Failure Self-care: Revised and updated. J Cardiovasc Nurs. 2016; 31(3):226-35. DOI: https://doi.org/10.1097/ JCN.0000000000000244

14. Riegel B, Lee CS, Dickson VV, Carlson B. An update on the self-care of heart failure index. J Cardiovasc Nurs. 2009; 24(6): 485-497. DOI: https://doi.org/10.1097/JCN.0b013e3181b4baa0

15. Organización Panamericana de la Salud. Guía para el diseño, utilización y evaluación de material educativo en salud. Serie PALTEX para Técnicos Medios y Auxiliares $N^{\circ} 10$. Copyright $(C$ Organización Panamericana de la Salud. Washington, D.C. [Internet]. 1984 [consultado el 6/02/2017]. Disponible en: http://www.fmed.uba.ar/depto/edunutri/2015guia.pdf

16. Barrera LF, Manrique FG, Opina JM. Propiedades psicométricas de instrumentos utilizados para evaluar material educativo en salud. Hacia promoc. Salud. 2011; 16(1):13-26.

17. Consejo de las organizaciones Internacionales de las Ciencias Médicas (CIOMS) en colaboración con la Organización Mundial de la Salud. Pautas éticas internacionales para la investigación biomédica en seres humanos. Ginebra. 2002. [Internet]. 2002 [consultado el 6/02/2017]. Disponible en: http://www. ub.edu/rceue/archivos/Pautas_Eticas_Internac.pdf

18. República de Colombia. Ministerio de Salud. Resolución número 8430 de 1993. Por la cual se establecen las normas científicas, técnicas y administrativas para la investigación en salud. Colombia. [Internet]. Santa Fe de Bogotá: El Ministerio; 1993 [consultado el 6/02/2017]. Disponible en: https://www. minsalud.gov.co/sites/rid/Lists/BibliotecaDigital/RIDE/DE/DIJ/RESOLUCION-8430-DE-1993.PDF

19. Fawcett J, Garity J. Conceptual-Theoretical-Empirical Structures for Research. In: Evaluating Research for Evidence-Based Nursing Practice. Philadelphia. Davis Company.2009. 21-35p.

20. Barbaranelli C, Lee CS, Vellone E, Riegel B. Dimensionality and reliability of the Self-care of Heart Failure Index scales: Further Evidence from confirmatory factor analysis. Res Nurs Health. 2014; 37(6):524-37. DOI: https://doi.org/10.1002/nur.21623

21. Correa Tello K. Diseño y validación de material para una intervención educativa en pacientes con implante de Stent coronario. Perspectivas Educativas [Internet]. 2014 [citado 20 de octubre de 2016]; 7(1):159-170. Disponible en: http://revistas.ut.edu.co/index.php/perspectivasedu/article/down$\underline{\text { load/674/519 }}$

22. Martínez CB, Cano N. Validación de contenidos de la herramienta educativa "fortaleciendo su cuidado infarto agudo al miocardio". [Trabajo grado Especialista]. Bogotá: Universidad Nacional de Colombia; 2010 [citado 20 de octubre de 2016]. Disponible en: http://www.bdigital.unal.edu. co/11332/1/539813.2012.pdf

23. Fernández A. Efecto de una intervención educativa de enfermería en la agencia de autocuidado del adulto mayor hipertenso de Boyacá, Colombia, Suramérica. [Tesis doctoral]. Bogotá: Universidad 
ISSN-PRINT

1794-9831

E-ISSN 2322-7028

Vol. 17 No. 1

Ene - Abr 2020

Cúcuta, Colombia

Nacional de Colombia; 2010 [citado 20 de octubre de 2016]. Disponible en: http://www.bdigital.unal. edu.co/8607/1/539192.2010.pdf

24. Paradis V, Cossette S, Frasure Smith N, Heppell S, Guertin MC. The efficacy of a motivational nursing intervention based on the stages of change on self-care in heart failure patients. J Cardiovasc Nurs. 2010; 25(2):130-41. DOI: http://doi.org/10.1097/JCN.0b013e3181c52497

25. Hernández Leiva E. Epidemiología del síndrome coronario agudo y la insuficiencia cardiaca en Latinoamérica. Rev Esp Cardiol. 2011; 64 (2):34-43. DOI: http://doi.org/10.1016/j.recesp.2011.01.022

26. Otsu H, Moriyama M. Effectiveness of an educational self-management program for outpatients with chronic heart failure. Jpn J Nurs Sci. 2011; 8(2):140-52. DOI: http://doi.org/10.1111/j.17427924.2010.00166.x

27. Valverde J. Diseño y elaboración de materiales didácticos multimedia. Nuevas tecnologías aplicadas a la comunicación. Badajoz. Universitas-ICE. Universidad de Extramadura. Departamento Ciencias de la Educación. [Internet]. 2004 [consultado el 4/05/2017]. Disponible en: http://cvonline.uaeh.edu.mx/ Cursos/Maestria/MTE/Gen02/Estra ensenanza edu dist/Est Ensenanza/Diseno de materiales didacticos multimedia $\% 5$ B $1 \% 5$ D.pdf

28. Bartolomé A. El diseño y producción de medios para la enseñanza. En J. Cabero (Ed.) Tecnología educativa, Madrid: síntesis, 71-86. [Internet] [consultado el 4/05/2017]. Disponible en: http://www. lmi.ub.es/personal/bartolome/articuloshtml/99DisenoProducMedios.pdf

29. Ziemendorff S, Krause A. Guía de Validación de Materiales Educativos (con enfoque en materiales de educación sanitaria). Primera edición. Programa de Agua y Saneamiento PROAGUA/GTP. Chiclayo, Perú. [Internet]. 2003 [consultado el 4/05/2017]. Disponible en: http://www.bvsde.paho.org/tutorialin/ pdf/eduperu.pdf

30. Liévano Fiesco M, García Londoño G, Leclercq Barriga M, Liévano De Lombo G, Solano Salazar K. Validación del material lúdico de la estrategia educativa basada en juegos para la promoción de estilos de vida saludable en niños de cuatro a cinco años de edad. Universitas Scientiarum. [Internet] 2009 [consultado el 4/05/2017]; 14(1):79-85. Disponible en: https://www.redalyc.org/articulo. oa? id $=49912232010$

31. Fawcett J, Garity J. Evaluation of the Utility of the Theory of practice. In: Evaluating Research for Evidence-Based Nursing Practice. Philadelphia. Davis Company.2009. 242-255p.

32. Meleis AI. Middle-Range and Situation-Specific Theorie. In: Theoretical Nursing: Development and Progress. Fifth Edition. Philadelphia. Wolters Kluwer/ Lippincott Williams \& Wilkins. 2012. p. 407424. 